\title{
MEIS2 Gene
}

National Cancer Institute

\section{Source}

National Cancer Institute. MEIS2 Gene. NCI Thesaurus. Code C104687.

This gene is involved in the regulation gene expression. 